\title{
「周辺機器」(He ガス中の不純物)
}

\author{
安藤道弘 \\ 日本酸素株式会社東京製作所 東京都大田区下丸子 2 丁目 12 番 15 号
}

(47年 7 月 3 日受理)

"Impurities in Helium Gas"

by Michihiro Ando

Tokyo Factory, Nippon Sanso Co., Ltd. 15 12, 2-Chome, Shimomaruko, Ōta-ku, Tokyo

(Received July 3, 1972)

\section{Synopsis :}

In the United States of America the natural gas which contains about $0.4 \%$ up helium content is used as main material for producing the helium gas. The equipment recently developed in France separates and rectifies $0.05 \%$ of helium gas to produce high purity of helium gas. This will serve as a good reference to how to go on with developing the helium resources in Japan.

The long and continuous operation of helium liquefier and refrigerator depends upon settling a problem that the impurities in helium gas is accumulated in the heat exchanger, as well as the good performance of compressor and turbine. We explain the present condition regarding the adsorbing method mainly adopted for purifying the helium gas. We have described so far the measuring principle and accuracy of the various analizers, like those for trace oxygen, nitrogen, moisture, methane and carbon doixide gas, as those closely related to the impurities in helium gas. Further we have discussed the comparison of various methods in case of purging the air in the air-tight vessels by using the helium gas, and the course of impurities entraining into the helium equipment having been examined.

冷凍液化技術における周辺機器といえばきわめて漠 然とした表題であり，また考え方によれば冷涷液化装 置のどのような型式にも必ず付随しておこる重要な問 題として，ここでは $\mathrm{He}$ ガス中の不純物に焦点を絞 り，これに関連する事項の概要を説明しよう。

\section{§1 He ガスの生産}

年間約 1590 の使用量の増加が期待され, 希有ガスよ り工業ガスの分野に脱皮しつつある $\mathrm{He}$ ガスは, 御承 知の如く天然ガス中に含まれる微量の $\mathrm{He}$ が深泠分離 法により抽出され, その殆んどが米国で生産されてい る。米国では天然ガス中の $\mathrm{He}$ の含有量 $0.4 \%$ 以上の ものが主としてその対照になっていて，0.4\%〜0.6\%

Vol. 7 No. 4 (1972)
の He ガス含有量の天然ガスは多量にあり，296程度 までのものも若干あるがこれ以上の含有量になると極 めて希れとなり，現在の最大含有量は $9 \%$ である。こ れ等の総計の $\mathrm{He}$ 埋蔵量は 56.6 億 $\mathrm{m}^{3}$ (1966 年推定) とされていて, 従来米鉱山局のみで生産していたもの を1960年代に民間企業にも生産を許可し，相ついで各 社が生産を始めた。Table 11) は, 米国における民間 の $\mathrm{He}$ 工場を示す。現在の民間の $\mathrm{He}$ 需要量 1,190 万 $\mathrm{m}^{3}$ と見込んでも約 2 倍の生産能力がある。

一方欧州に打ける $\mathrm{He}$ ガスの生産の一例をあげる と, オランダの Groningen の井戸から噴気する天然

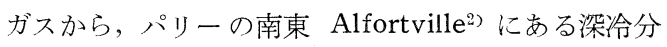
離装置にて, $\mathrm{N}_{2}$ と $\mathrm{He}$ の抽出を行なっている。この 
装置注 Table 2 に示すように, 原料ガス $65,000 \mathrm{Nm}^{3}$ $/ \mathrm{hr}$ より，25atm の中圧メダンガス $40.950 \mathrm{~m}^{3} / \mathrm{hr}$ と, $1.1 \mathrm{~atm}$ の低圧メタンガス $15,899 \mathrm{~m}^{3} / \mathrm{hr}$ 抢よび 窒素ガス $8.112 \mathrm{~m}^{3} / \mathrm{hr}$ を産出物として生産している ものであるが，この装置の副産出物として原料ガス中 飞含まれている $0.05 \%$ の $\mathrm{He}$ ガスを精製し， $\mathrm{N}_{2}$ が $5 \mathrm{ppm}$ 以下の高純 He ガスを生産している。Fig. 1 飞装置の系統図示す。原料の天然ガスは $42 \mathrm{~atm} に$ 圧縮され, 活性アルミナの充填された乾燥器中にてべ
ンゼンのような重質性分の炭化水素系を吸着し，さら にアルミニウム製のプレート熱交換器中にて哭りガス により $175^{\circ} \mathrm{K}$ まで泠却されて炭酸ガス筒に入る。こ の筒内で頂部より $\mathrm{CO}_{2}$ を含有しないガスと，底部よ り $\mathrm{CO}_{2}$ の $2 \%$ 以下のガスに分離して, 作動圧力 26 atmの中圧筒内に導入される。この筒の年出物は熱交 換後常温になり, 中圧メタンガスとして装置外に取り 出され，また中圧筒の留出物として $\mathrm{CH}_{4}, 1 \%$ 以下 $\mathrm{He} ， 10 \%$ の混合ガスに精留されて引抜かれる。さら

Table 1 米国における民間 $\mathrm{He}$ 工場 (1969年 現在)

\begin{tabular}{|c|c|c|c|c|}
\hline \multirow[b]{2}{*}{ 会 } & \multirow[b]{2}{*}{ 工 場 所 在 地 } & \multirow[b]{2}{*}{ 操業開始 } & \multicolumn{2}{|c|}{ 年 間 能力 $\left(\right.$ 一万 $\left.\mathrm{m}^{3}\right)$} \\
\hline & & & $\begin{array}{c}\text { Crade A } \\
(99.995 \%) \\
\text { He ガス }\end{array}$ & $\begin{array}{c}\mathrm{LHe} \\
\text { (ガス換算) }\end{array}$ \\
\hline Kerr-McGee Corp. & Narajo, Ariz. & 1961 & 198 & 65 \\
\hline Kansas Reîned Helium Co. & Otis, Kans. & 1965 & 510 & 510 \\
\hline Alams. Chemical Co. & Elkhart, Kans. & 1966 & 396 & 396 \\
\hline U.C.C. Limde Division & Amarills, Texas. & 1968 & 170 & 170 \\
\hline Air Reduction Co. & Teec Nos Pos, Ariz. & 1968 & 57 & 0 \\
\hline Air Reduction Co. & Shiprock, N. Mex. & 1968 & 272 & 0 \\
\hline Cities Service Cryogenic & Ulysses, Kans. & 1968 & 566 & 467 \\
\hline Arizona Helium Co. & Navajo, Ariz. & 1969 & 34 & 0 \\
\hline & 計 & & 2,203 & 1,608 \\
\hline
\end{tabular}

Table 2 Alfort ville 装置の設計諸元

\begin{tabular}{|c|c|c|c|c|c|c|c|c|}
\hline Fraction & \multicolumn{2}{|c|}{$\begin{array}{l}\text { Natural gas } \\
\text { after drier }\end{array}$} & \multicolumn{2}{|c|}{$\begin{array}{c}\text { MP-fraction } \\
\text { Medium } \\
\text { Pressure }\end{array}$} & \multicolumn{2}{|c|}{$\begin{array}{c}\text { LP-fraction } \\
\text { Low } \\
\text { Pressure }\end{array}$} & \multicolumn{2}{|c|}{ Nitrogen } \\
\hline Flow $\begin{aligned} \mathrm{Nm}^{3} / \mathrm{h} \\
\\
\mathrm{Mscfd}\end{aligned}$ & \multicolumn{2}{|c|}{$\begin{array}{l}65,000 \\
58,188\end{array}$} & \multicolumn{2}{|c|}{$\begin{array}{l}40,950 \\
36,658\end{array}$} & \multicolumn{2}{|c|}{$\begin{array}{l}15,899 \\
14,233\end{array}$} & \multicolumn{2}{|c|}{$\begin{array}{l}8,112 \\
7,262\end{array}$} \\
\hline \multirow[t]{2}{*}{$\begin{array}{r}\text { Pressure atm } \\
\text { psia }\end{array}$} & \multicolumn{2}{|c|}{$\begin{array}{r}42 \\
595\end{array}$} & \multicolumn{2}{|c|}{$\begin{array}{r}25 \\
355\end{array}$} & \multicolumn{2}{|c|}{$\begin{array}{r}1.1 \\
16\end{array}$} & \multicolumn{2}{|c|}{$\begin{array}{r}1.1 \\
16\end{array}$} \\
\hline & $\mathrm{Nm}^{3} / \mathrm{h}$ & mole & $\mathrm{Nm}^{3} / \mathrm{h}$ & $\underset{\%}{\text { mole }}$ & $\mathrm{Nm}^{3} / \mathrm{h}$ & $\begin{array}{c}\text { mole } \\
\%\end{array}$ & $\mathrm{Nm}^{3} / \mathrm{h}$ & $\underset{\%}{\operatorname{mole}}$ \\
\hline $\begin{array}{l}\text { Components } \\
\qquad \mathrm{N}_{2}\end{array}$ & 9,295 & 14.30 & 885 & 2.16 & 318 & 2.00 & 8,086 & 99.68 \\
\hline $\mathrm{CH}_{4}$ & 52,747 & 81.15 & 37,140 & 90.70 & 15,581 & 98.00 & 26 & 0.32 \\
\hline $\mathrm{C}_{2} \mathrm{H}_{6}$ & 1,885 & 2.90 & 1,885 & 4.60 & & & & \\
\hline $\mathrm{C}_{3} \mathrm{H}_{8}$ & 260 & 0.40 & 260 & 0.63 & & & & \\
\hline $\mathrm{C}_{4}$ & 195 & 0.30 & 195 & 0.48 & & & & \\
\hline $\mathrm{CO}_{2}$ & 585 & 0.90 & 585 & 1.43 & & & & \\
\hline $\mathrm{He}$ & 33 & 0.05 & & & & & & \\
\hline
\end{tabular}




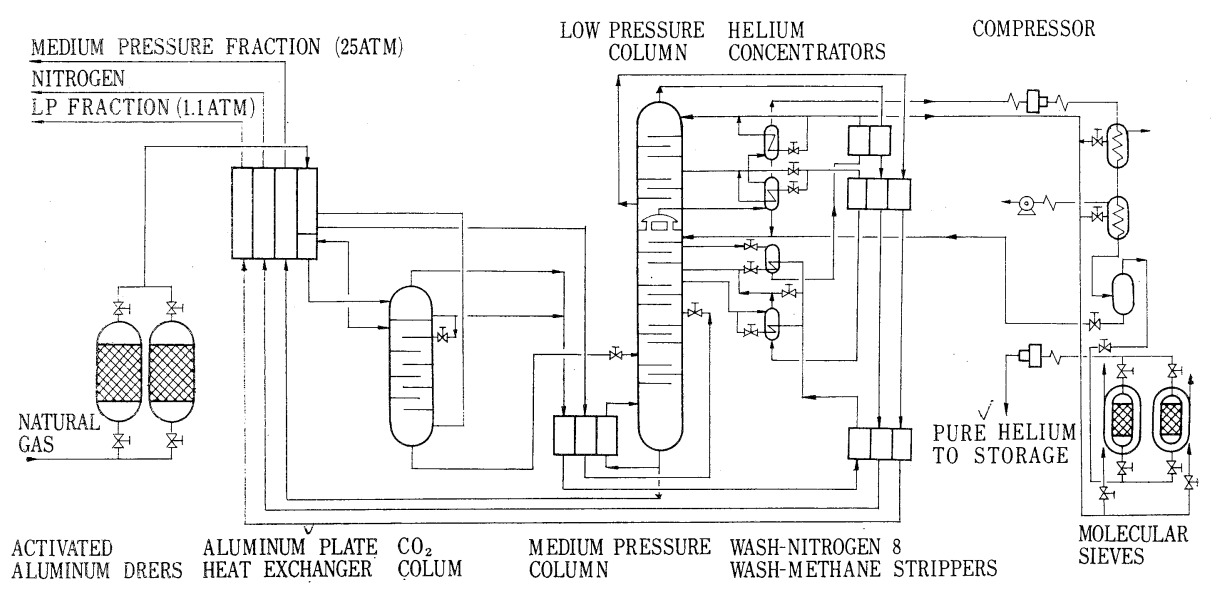

Fig. 1 Schematic flow diagram of Alfortiville plant

に $\mathrm{He}$ 凝縮器内にて $\mathrm{N}_{2}$ および $\mathrm{CH}_{4}$ を凝縮分離して 86 90\% の He ガスとなる。このガスはダイアフラ ム圧縮機にて $200 \mathrm{~atm}$ に昇圧され液体窒素で泠却し た後モレキュラーシーブ中にて不純物を完全に除去し 窒素 $5 \mathrm{ppm}$ 以下の高純度 He が製造されている。

ここで特にフランスの $\mathrm{He}$ ガス製造装置の例を述心 たのは天然ガス $65,000 \mathrm{~N} \mathrm{~m}^{3} / \mathrm{hr}$ の中にわずかに $\mathrm{He}$ ガス $33 \mathrm{~m}^{3} / \mathrm{hr}$, 即ち, 濃度 $0.05 \%$ に相当する微量ガ スを複雑な深冷分離操作を行なって抽出していること である。前述したごとく米国では $\mathrm{He} 0.4 \%$ 以上を含 有する天然ガス上りのみ $\mathrm{He}$ の抽出を行なっているの に比較してこの場合は一桁低い含有量の天然ガスより $\mathrm{He}$ を抽出している。この事実は，近い将来わが国が 天然ガスを多量に利用しようといら気運にあり，いず れは資源を求めて開発に取り組むことになるだろら が，この場合，フランスにおけるように極めて低含有 量の $\mathrm{He}$ まで抽出して $\mathrm{He}$ 資源を確保している姿は, 大いに参考になると思う。

\section{$\S 2 \mathrm{He}$ ガス中の不純物の除去}

He 液化機およで椧涷機において，長期連続運転を 継続するのに障害となるものは先ず回転機の信頼性で あり，次に $\mathrm{He}$ ガス中の不純物による熱交換器の閉塞 および熱交換量の低下である。現在冷凍液化装置に利 用されている不継物の除去方式として，切替式熱交換 器に代表される凍結方式, 分縮器に代表される凝縮方 式，炭酸ガスの苛性ソーダ溶液による吸収に代表され る化学反応方式, 蓄冷器, 可逆熱交換器に代表される 過負荷量方式, およびモレキュラーシーブ, 活性アル
ミナに代表される吸着方式等が利用されている。この 中で $\mathrm{He}$ の泠凍液化機に利用されるのは, 現在では吸 着方式に限定されているので, 主として低温における 吸着方式について述べる。

高純度の He を精製する場合，液体窒素の温度で極 く微量の $\mathrm{N}_{2}$ または炭化水素を物理吸着により処理す る方法が一般装置に使用されているが， $\mathrm{N}_{2}$ および炭 化水素の低温における吸着剤の平衡吸着量, 吸着体中 を流れる場合の $\mathrm{He}$ 中の不純物の動的吸着の設計資料 に役立つ報文は殆んどない。

しかし，次のような A. J. Kidnay 等の仕事がある。 彼等は吸着体 ${ }^{2)}$ (Caconut Shell charcoal) として 8 10 メッシュ, 代表径 $0.193 \mathrm{~cm}, \mathrm{~N}_{2}$ ガスでの B. E. T 表面積 $904 \mathrm{~m}^{2} / \mathrm{gr}$ の活性炭を使用し，再生は実験每 に $200^{\circ} \mathrm{C}$ で 12〜18 時間加熱した後純 $\mathrm{He}$ ガスで冷却 をしたものを使用した。また実験装置は吸着層の長さ $6.4 \mathrm{~cm}$, 吸着層の直径 $1.91 \mathrm{~cm}$, ののを用いて, 等 温吸着平衝および動的吸着の実験を行なった。

Fig. 2 は $\mathrm{He}$ ガス中へ $\mathrm{N}_{2}$ ガス $1,070 \mathrm{ppm}$ を添 加し液体窒素の 温度で等温吸着をした場合を示し，

Fig. 3 は $\mathrm{He}$ ガス中へ $\mathrm{CH}_{4}$ を $480 \mathrm{ppm}$ 加えた場合 の等温吸着を示したもので，圧力の増加と共に吸着量 も増加する傾向を示すが， $\mathrm{H}_{2}$ ガス ${ }^{4)}$ 中では圧力の増 加と共に $\mathrm{N}_{2}$ および $\mathrm{CH}_{4}$ の吸着量は減少する傾向に あるのと対蹠的である。

活性炭の層中を微量な $\mathrm{N}_{2}$ および $\mathrm{CH}_{4}$ を不純物と して含有した He ガスが通過する場合の吸着行程とし て，(1)吸着体の表面へ $\mathrm{He}$ ガス相中の不純物の拡散速 度と(2)吸着体の内部での $\mathrm{He}$ ガス相中の不純物の桩散 
速度とが考えられる。Fig. 4 は 2 成分系の破過状態 を示す。横軸にガスを層内に流し始めてよりの時間を 取り, 縦軸に $\mathrm{C} / \mathrm{C}_{0}=$ ガス出口の不純物の濃度/ガス 入口の不純物の濃度を取った。この場合(1)よび(2が 極めて敏速な拡散速度を常時維持するとす秃ば破過点 に到達すると段階的に $\mathrm{C} / \mathrm{C}_{0}=1$ の值一上昇するが， 実際に拡散速度の何れかが遅れるため破過状態は $\mathrm{S}$ 型 になる。 He ガス中に $1,070 \mathrm{ppm} の \mathrm{~N}_{2}$ ガスを不純 物として含有し流速 $\mathrm{G}=61 \mathrm{~g} / \mathrm{hr}-\mathrm{cm}^{2}$ にて流した場 合と $\mathrm{He}$ ガス中に $480 \mathrm{ppm}$ の $\mathrm{CH}_{4}$ ガスを不純物と して含有し流速 $132 \mathrm{~g} / \mathrm{hr}^{-} \mathrm{cm}^{2}$ の時の液体窒素温度に て吸着を行なった場合の破過状態を示す。Fig. 5 は 三成分系として $\mathrm{He}$ ガス中の不純物として $\mathrm{CH}_{4} 690$ $\mathrm{ppm}$ と $\mathrm{N}_{2} 1,460 \mathrm{ppm}$ の混合ガスを流速 $50 \mathrm{~g} / \mathrm{hr}$ $\mathrm{cm}^{2}$ にて液体窒素の温度にて動吸着を行なった時の破 過点以後の状態を示す。この図では先ず 40 分後に $\mathrm{N}_{2}$ が破過点に到達し急激に $\mathrm{C} / \mathrm{C}_{0}$ の值が増加して 1.0 以上になる。一方 $\mathrm{CH}_{4}$ は 100 分後に破過点に到達し

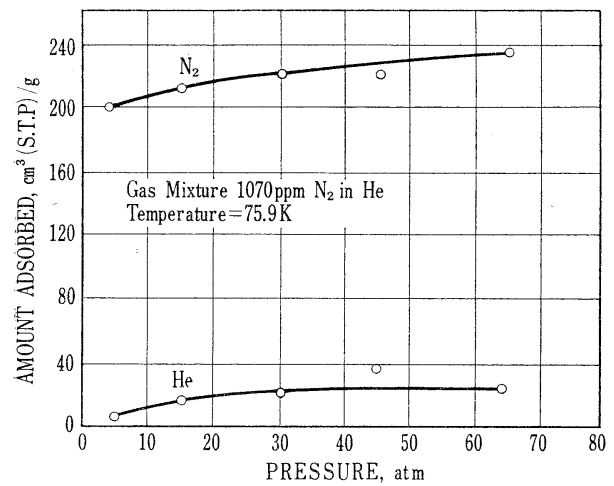

Fig. 2 Adsorption of a nitrogen-helium mixture.

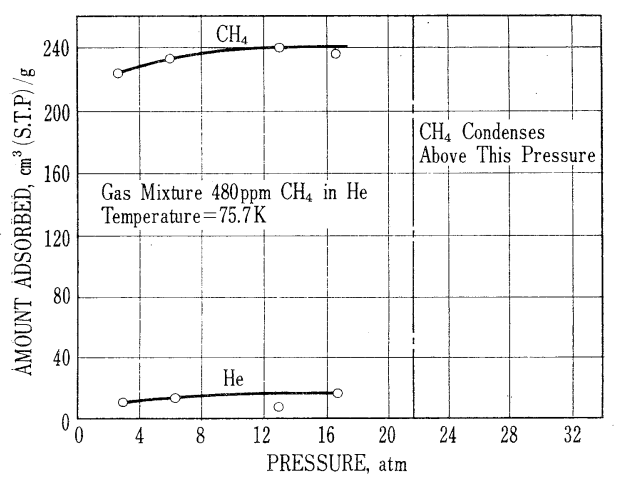

Fig. 3 Adsorption of a methane-helium mixture.
以後 $\mathrm{S}$ 型を示して除々に $\mathrm{C} / \mathrm{C}_{0}$ が 1.0 に到達する。こ の現象は $\mathrm{CH}_{4}$ が $\mathrm{N}_{2}$ より吸着力が強く一度吸着され ていた $\mathrm{N}_{2}$ を追出して $\mathrm{C} / \mathrm{C}_{0}$ の值が 1.0 より大きく なると推定されている。このように吸着体はその挙動 が複雑であり，破過点を推定するための物質移動系数 を定量的に解折することが困難なため, 設計上の資料 として化学工学的な取扱いのでき得る段階にまでの解 折方法が確立されていなく, He ガス中の微量不純物 を除去する場合の有力な方法である吸着方式の解折は 低温工学者の手によって今後さらに開発されるものと 期待している。

\section{3§ He 中に含まれる微量不純物のプロセス 用分析計}

a) 微量酸素……ガルバニック電池法は電解液中に 試料ガス中の $\mathrm{O}_{2}$ 泼溶解させそれを電気化学的に測定 する。このガルバニック電池は不活性陽極の $\mathrm{O}_{2}$ によ る復極作用によって，溶解した $\mathrm{O}_{2}$ 量によって比例す

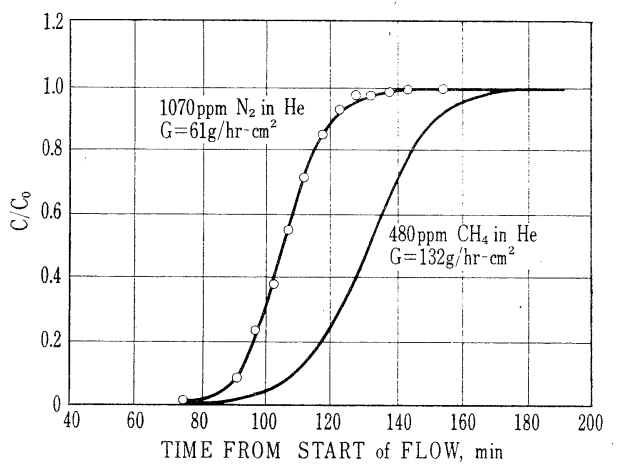

Fig. 4 Typical breakthrough curves for binary mixtures.

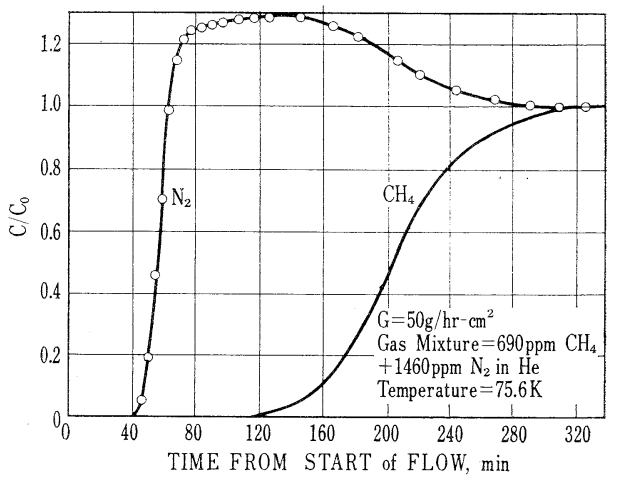

Fig. 5 Typical breakthrough curve for ternary mixture.

低温工学 
る電流を発生する。測定範囲は 0〜100 ppm でその精 度は全目盛の $\pm 5 \%$ 程度が標準である。

触媒反応法は $\mathrm{O}_{2}$ と反応するに充分な $\mathrm{H}_{2}$ とを白金 パラジウム触媒により反応させ，その際に発生する熱 量による温度上昇から $\mathrm{O}_{2}$ 量を測定する測定範囲 0 $200 \mathrm{ppm}$ その精度は土2\%程度である。

黄燐発光法は黄燐蒸気中に微量の $\mathrm{O}_{2}$ を含むガスを 吹きこめば黄燐と $\mathrm{O}_{2}$ が反応し光を発生する。その発 光エネルギーは $\mathrm{O}_{2}$ の量に比例しその光を測定して $\mathrm{O}_{2}$ を求める。測定範囲は $0 \sim 50 \mathrm{ppm}$ 精度は土 2 \%であ る。

濃淡電池法は $\mathrm{O}_{2}$ 分圧の高い極で $\mathrm{O}_{2}$ が電子を得て $\mathrm{O}_{2}$ イオンとなりセラミック内を移動し一方の極で $\mathrm{O}_{2}$ ガスに戾る。このさい Nernst の式による起電力を生 ずる。測定範囲 0.1 1.0\% で精度は土 $2 \%$ であ。

b) 微量窒素……紫外線スペクトル法は希ガスに高 電圧を作用させて白熱放電を起させると $\mathrm{N}_{2}$ は励起さ れて $3,371 \AA$ の紫外線光を発する。この紫外線スぺ クトルの強さは $\mathrm{N}_{2}$ の濃度に比例する。測定範囲 0 $100 \mathrm{ppm}$ 精度は土 $2 \%$ 。

c) 微量水分……電気化学的方法はガス中の水分を ロジウム電極の間に支えられた $\mathrm{P}_{2} \mathrm{O}_{5}$ のうすい皮膜に 吸収させ，電極に直流電圧をかけて吸収した $\mathrm{H}_{2} \mathrm{O}$ を $\mathrm{H}_{2}$ と $\mathrm{O}_{2}$ に電解する。この電解の際に Faraday の法 則に従って, 試料中の水分量に比例した電流が得られ る。測定範囲 $0 \sim 1,000 \mathrm{ppm}$ で精度は土 $5 \%$ 。

電気容量法はアルミニウムの表面に多孔質の酸化ア ルミニウムの薄膜を形成せしめたものを陽極とし，こ れに蒸着した金の薄膜とが，蓄電池を構成している。 水蒸気はその圧力に比例して薄膜内に拡散し吸着され る。その多孔壁に吸着された $\mathrm{H}_{2} \mathrm{O}$ 分子の量に比例し て両電極間の電気容量が变化する。測定範囲は露点$110 \sim+10^{\circ} \mathrm{C}$ で精度は土1\%で女る。

d) 微量メタン, 炭酸ガス……水素炎法は炭素原子 を含んだ試料ガスを水素炎中を通すとイオン化がおこ る。このイオン流から微量炭化水素の量が測定できる。 ppm〜9ó order まで精度は土1\%である。

赤外法は試料ガス中の 2 原子分子が特定波長の赤外 線を吸収することを利用して特定成分の濃度を測定す る。測定範囲は ppm〜 100\% まで精度は $\pm 1 \%$ であ る。

ガスクロマトグラフ法は試料の一定量をキャリヤガ スと共に分離カラムに導入して各成分に分離し, 熱伝 導セルその他の検出器で測定する。測定範囲は ppm〜

Vol. 7 No. 4 (1972)
100\% である。

\section{$\S 4$ パージの方式}

気密容器内の空気を $\mathrm{He}$ ガスでパージする場合の一 般に使用される方法は, 混合放出, 真空とガス注入の 併用，加圧放出による方法がある。

a) 混合放出による方法……机は気密容器内に $\mathrm{He}$ ガスを高速度で噴射させ，内部の空気を $\mathrm{He}$ と混 合して放出するという最も簡単なパージ法である。こ の方法でパージした時の気密容器内の雲囲気中に含ま れる空気濃度 $(A \%)$ は次式で求められる。

$$
\mathrm{A}=100 \mathrm{e}^{-\mathrm{Ft} / \mathrm{V}}
$$

ここで F は $\mathrm{He}$ ガスの流量 $\left(\mathrm{m}^{3} / \mathrm{hr}\right)$, ‘ は時間 $(\mathrm{hr})$, $\mathrm{V}$ は気密容器内の容積 $\left(\mathrm{m}^{3}\right)$ である。この式は, すべ ての時間において空気と He ガスが完全に混合するも のと仮定して求めてあるので, 実際にはこれらの計算 量よりやや多量の He ガスが必要となる。一例として 雲囲気中の空気濃度を $10 \mathrm{ppm}$ に低減するのに計算值 の約10倍量の He ガスを要した。この混合放出方式は パージの効率も悪く，また不確実な結果を生じやすい ものである。

b) 真空と $\mathrm{He}$ ガス注入の併用方式……この方法は 気密容器内の空気を真空引きしたのち, He ガス充 たす方法で，a）の場合に比較して He の消費量は少 ない。気密容器中の空気濃度を A 名 は次式で求めるこ とができる。

$$
\mathrm{A}=100 / \mathrm{Rn}^{\mathrm{n}}
$$

ここで $\mathrm{A}$ は気密容気中の空気濃度 $(96), \mathrm{n}$ は真空ガス注入の操作回数, R の圧力を示す。

しかし,この方法では真空系統の装置が必要であり, 気密容器もまた真空に耐え得る構造であることが必要 条件で，その費用を見込まねばならぬ。

c）加圧放出による方法……の方法は気密容器内 が数気压になるまで不活性ガスを充てんし，充てんの 各回每にガスを大気圧になるまで放出する操作を繰返 して空気をパージする。その排気ごとに空気は不活性 ガスと共に除去される。加圧した時の容気内のガス圧 力 $/$ 大気圧 $=\mathrm{R}$ とす机ば, 前述の $\mathrm{b}$ 項の式がこの場合 にも適用することができる。

\section{$5 \S$ 不純物の混入径路}

He の泠涷液化において $\mathrm{He}$ 中へ不純物の混入する 可能性の比較的強いと思われる点を列挙すれば下記の 
通りである。

a）駆動部分の軸封部としてピストンロッドパッキ ング部および弁のパッキン部がある

b ）局部的に負圧になる場所，例えば圧縮機の吸入 配管

c）圧縮機停止時に軸封部への供気の中断により, 再起動時に空気を吸い込むため，でき得れば軸封部一 の供気は圧縮機の停止時も継続するよう工夫が必要で ある

d) 圧力計，弁等のデッドスペスに残留するガス

e）合成樹脂の透過および吸着ガス分子の脱着によ るガス

f）配管の小さな孔よりの逆拡散

g）油と $\mathrm{He}$ ガスとの接触がある場合油中に溶解し ているガスのストリッピングによる場合

等が考えられる。 $\mathrm{He}$ ガス中への不純物の混入は $\mathrm{ppm}$ の数值でも 熱交換器の閉塞を起す原因になるた め，特に大型の冷凍液化装置では問題として大きくク ローズアップされてくる。

以上 $\mathrm{He}$ ガス中の不純物に関連する範囲に絞って䌂 めたが，冷凍液化装置の運転に携わる技術者諸賢に多 少とも参考になる点があれば枯甚である。

\section{参考 文 献}

1)門奈五兵：「米国におけるへリウムの全貌」未 発表

2) Matin Streich : Hydrocarbon Processing, April (1970) 86 88.

3) A. J. Kidnay and M. J. Hiza : AICHE Journal Vol. 16, No. 6 (1970) 949 954

4) A. J. Kidnay, M. J. Hiza and P.F. Dickson : "Advances in Cryogenic Engineering" Vol. 13 (1968) 397 408. 